\title{
Microbial Quality of "Tchachanga", a Barbecued Mutton Sold in Benin
}

\author{
Kadoéito Cyrille Boko, Martial Gangnito' ${ }^{1}$, Soumanou S. Toleba ${ }^{2}$, Philippe Sessou ${ }^{1}$, \\ Ulbad Polycarpe Tougan³ ${ }^{3}$ Oscar Nestor Aguidissou', Marc T. Kpodekon'1, Souaïbou Farougou ${ }^{1}$ \\ ${ }^{1}$ Université d'Abomey-Calavi, Ecole Polytechnique d'Abomey-Calavi, Département de Production et Santé Animales, Unité de \\ Recherche en Biotechnologie de la Production et de la Santé Animales, Abomey-Calavi, République du Bénin \\ ${ }^{2}$ Université d’Abomey-Calavi, Faculté des Sciences Agronomiques, Cotonou, République du Bénin \\ ${ }^{3}$ Université de Parakou, Faculté d'Agronomie, Parakou, République du Bénin \\ Email: cyrilleboko@yahoo.fr
}

How to cite this paper: Boko, K.C., Gangnito, M., Toleba, S.S., Sessou, P., Tougan, U.P., Aguidissou, O.N., Kpodekon, M.T. and Farougou, S. (2017) Microbial Quality of "Tchachanga", a Barbecued Mutton Sold in Benin. Advances in Microbiology, 7, 633-640.

https://doi.org/10.4236/aim.2017.78049

Received: July 25, 2017

Accepted: August 26, 2017

Published: August 29, 2017

Copyright $\odot 2017$ by authors and Scientific Research Publishing Inc. This work is licensed under the Creative Commons Attribution International License (CC BY 4.0).

http://creativecommons.org/licenses/by/4.0/

\begin{abstract}
The microbial quality of Tchachanga, a barbecued mutton sold at Bohicon and Hilla-Condji bus stations in Benin was assessed in accordance with French standards (DGAL, 2000). The analyses revealed that the average total viable counts (TVC) recorded in Bohicon $\left(3.96 \times 10^{8} \mathrm{cfu} / \mathrm{g}\right)$ and Hilla-Condji $(5.51 \times$ $\left.10^{8} \mathrm{cfu} / \mathrm{g}\right)$ exceeded standard safety limits $\left(3 \times 10^{5} \mathrm{cfu} / \mathrm{g}\right)$. Similar observations were made for other parameters such as fecal coliforms count, Escherichia coli count, sulphite-reducing anaerobes, Staphylococcus aureus, yeasts and molds. Salmonella sp were absent in all samples. There was no significant difference $(\mathrm{P}>0.05)$ between the microbial loads obtained in Bohicon and Hilla-Condji. This study shows that barbecued mutton sold in these two stations is unsafe for human consumption. It is therefore important for food safety authorities in Benin to take appropriate measures and sensitize sellers on strict observance of hygiene rules in order to preserve public health.
\end{abstract}

\section{Keywords}

Food Safety, Tchachanga, Street-Vended Food, Microorganisms, Public Health

\section{Introduction}

In recent years, the phenomenon of rapid urbanization in developing countries has not spared Benin, where the urban population is growing steadily. This rapid and intensive urbanization together with unemployment and economic crisis have enhanced the growth of street-vended foods [1]. Street-vended foods are ready-to-eat foods prepared and sold by vendors or hawkers primarily along the 
streets and public places [2]. They play an important role in the daily lives of thousands of people whose education and food processing skills are often limited and who initiate this professional activity primarily to escape poverty and provide consumers with low-cost foods [3]. While street-vended foods are a cost-effective solution for nutritional needs in developing countries, the conditions for their preparation, processing, preservation and distribution do not always ensure the quality, safety and hygiene required [4]. The main concern of these foods is their poor microbiological quality, mainly because their production and sale sometimes take place in unhygienic environments. They are often contaminated with pathogenic microorganisms that cause diarrheal diseases to consumers [5]. Among these street-vended foods, meats are of paramount importance. The composition of meat makes it an excellent proliferation medium for many microorganisms, particularly bacteria [6]. Epidemiological studies have identified consumption of meat and meat products as important risk factors for diarrheal diseases such as salmonellosis, foodborne illnesses caused by $E$. coli, $S$ aureus and Clostridium perfringens [7] [8]. In Benin, mutton is transformed into a number of derived products, including tchachanga, a barbecue generally sold along the streets by vendors with low levels of education [9] [10]. It is an important source of animal proteins for the populations, but unfortunately produced and sold under unhygienic conditions leading to its contamination by pathogenic microorganisms having negative impacts on the health of consumers. It is therefore important to assess the microbiological quality of this meat in order to assess safety risks to consumers. The available literature revealed a lack of data on the quality of this food sold outside the city of Cotonou in Benin. To fill this gap of knowledge, the present study aimed to assess the microbiological quality of barbecued mutton sold at Bohicon and Hilla-Condji bus stations in Benin.

\section{Material and Methods}

\subsection{Study Area}

The study was conducted from May to October 2016 at two bus stations in Benin: Hilla-Condji stations at the Benin-Togo border and Bohicon station along the Inter State Benin-Niger road (150 km from Cotonou, the main economic city of Benin).

\subsection{Sampling}

Barbecued mutton were sampled from vendors in both sites. The samples (Table 1) were taken one day per week for 7 weeks as per ISO 17604: 2003 standards. The sampling day varied weekly so that the results were representative of the entire week. On each sampling day, four samples were taken, i.e. 28 samples per bus station. Collected samples (around $250 \mathrm{~g}$ per sample) were placed in sterile stomacher bags and stored in a container with cooling element. Samples were then transported to the laboratory within 4 hours and immediately analysis. 
Table 1. Sampling days and sample size per week.

\begin{tabular}{cccc}
\hline \multirow{2}{*}{ Weeks } & Days & \multicolumn{2}{c}{ Sample size } \\
\cline { 3 - 4 } & Monday & Bohicon & Hilla-Condji \\
\hline \multirow{2}{*}{2} & Friday & - & - \\
& Tuesday & 4 & - \\
\multirow{2}{*}{3} & Saturday & - & 4 \\
& Wednesday & 4 & - \\
4 & Sunday & - & 4 \\
& Thursday & 4 & 4 \\
5 & Monday & - & - \\
& Friday & 4 & 4 \\
6 & Tuesday & - & - \\
& Saturday & 4 & - \\
7 & Wednesday & - & 4 \\
\hline
\end{tabular}

\subsection{Enumeration and Research of Microorganisms}

\subsubsection{Preparation of Serial Dilutions}

Serial dilutions were made from the various samples according to ISO 6887-3: 2003. A stock solution was prepared by crushing $25 \mathrm{~g}$ of each sample in $225 \mathrm{ml}$ of Buffered peptone water (BPW). For each sample, $1 \mathrm{ml}$ of the stock solution was aseptically added using a sterile, graduated glass pipette into a sterile tube containing $9 \mathrm{ml}$ of diluent to make the dilution $10^{-1}$. Thereafter, $1 \mathrm{ml}$ of the dilution $10^{-1}$ was aseptically introduced into another sterile tube containing $9 \mathrm{ml}$ of the same diluent to make dilution $10^{-2}$. The procedure was repeated until dilution $10^{-6}$.

\subsubsection{Total Viable Count (TVC)}

TVC was performed according to ISO 4833: 2003. $1 \mathrm{ml}$ of the stock suspension and its dilutions were added in sterile petri dishes then $10-15 \mathrm{ml}$ of Plate Count Agar (PCA Oxoïd CM 0325), was poured into it, and then the whole was perfectly homogenized. After complete solidification, the plates were turned over and incubated at $30^{\circ} \mathrm{C}$ for 72 hours. The assay was done in triplicate for each dilution.

\subsubsection{Fecal Coliforms Count}

Fecal coliforms were enumerated according to ISO 4832: 2006. $1 \mathrm{ml}$ of the stock solution and its dilutions were placed in sterile Petri dishes. Violet Red Bile Glucose Agar (VRBG LAB 88) was then added. After solidification, a second layer was made. After complete solidification, the plates were turned over and incubated at $44^{\circ} \mathrm{C}$ for 24 hours.

\subsubsection{Escherichia coli}

E. coli strains were counted according to AFNOR BRD-07/1-07/93. From the VRBG plates containing about 15 and 150 typical colonies, five colonies were 
removed and subcultured onto Eosin Methylene Blue (EMB) agar. After 24 hours of incubation at $37^{\circ} \mathrm{C}$, colonies that appeared in a bright metallic form were considered characteristic for $E$. coli.

\subsubsection{Staphylococcus aureus}

S. aureus was counted according to ISO 6888-1: 1999. We used Baird-Parker media (LAB 85), incorporated in egg yolk and potassium tellurite (Oxoïd SR 0054C). The precast medium was cultured on the surface with $0.1 \mathrm{ml}$ of the stock solution or its decimal dilutions. The plates were incubated at $37^{\circ} \mathrm{C}$ for 24 to 48 hours. Colonies appearing black, shiny, bulging, surrounded by an opaque white border and a lightening halo were considered characteristic for $S$. aureus.

\subsubsection{Sulphite-Reducing Anaerobes}

Sulphite-reducing anaerobes were detected according to ISO 15213: $2003.5 \mathrm{ml}$ of the stock solution and its dilutions were placed in sterile tubes after heating for $10 \mathrm{~min}$ at $80^{\circ} \mathrm{C}$ in a water bath to destroy the vegetative forms. Then, trypticase-Sulfite-Neomycin (Biokar) agar kept at $45^{\circ} \mathrm{C}$ was added. After complete solidification, the tubes were incubated at $37^{\circ} \mathrm{C}$ for 24 hours.

\subsubsection{Yeasts and Molds NF ISO 7954: 1998}

The counts were made on Sabouraud Dextrose Agar with Chloramphenicol. The medium was cultured on the surface with $0.1 \mathrm{ml}$ of the stock solution and its decimal dilutions. The plates were incubated at $25^{\circ} \mathrm{C}$ for 5 days. Colonies that appeared whitish and milky are those characteristic of yeasts while the other forms are molds.

\subsubsection{Salmonella $s p$}

The search for Salmonella sp was done according to ISO 6579: 2002. It was carried out in four successive steps. A pre-enrichment was performed by homogenizing $25 \mathrm{~g}$ of the sample in $225 \mathrm{ml}$ of buffered peptone water incubated at $37^{\circ} \mathrm{C}$ for $18 \mathrm{~h} \pm 2 \mathrm{~h}$, followed by an enrichment in Rappaport Vassiliadis broth incubated at $41.5^{\circ} \mathrm{C}$ for $24 \mathrm{~h}$. Isolation was carried out on XLD agar incubated at $37^{\circ} \mathrm{C}$ for $24 \mathrm{~h}$. The biochemical identification of the presumptive isolates was carried using API 20E strips.

\subsection{Statistical Analyses}

Data were recorded in a designed Excel database. The SAS 9.2 software [11] was used for statistical analysis. The mean microbial loads of each of the microbiological parameters were calculated per location and the comparisons between these values were made two by two using the student t-test after an analysis of variance to determine the zone effect.

\section{Results and Discussion}

\subsection{Results}

The microbiological characteristics of barbecued mutton samples collected at 
Bohicon and Hilla-Condji bus stations are shown in Table 2. The average microbial loads of TVC are $3.96 \times 10^{8} \mathrm{cfu} / \mathrm{g}$ in Bohicon and $5.51 \times 10^{8} \mathrm{cfu} / \mathrm{g}$ in Hilla-Condji. These values are higher than the critical limits $\left(3 \times 10^{5} \mathrm{cfu} / \mathrm{g}\right)$ set by French regulations (2000) [12], which indicates the unsatisfactory nature of the different samples analyzed. Fecal coliforms are present in the samples investigated at high levels $\left(3.81 \times 10^{3}\right.$ to $4.28 \times 10^{3} \mathrm{cfu} / \mathrm{g}$ respectively in both sites) compared to the standard limit $(10 \mathrm{cfu} / \mathrm{g})$. Similar observations were made for $E$. coli. Likewise, the counts of $S$. aureus and sulphite-reducing anaerobes, in Hilla-Condji and Bohicon exceeded the tolerance thresholds required by the same regulations. For yeasts and molds, the average microbial loads in Bohicon and Hilla-Condji were $9.61 \times 10^{2} \mathrm{cfu} / \mathrm{g}$ and $12.14 \times 10^{2} \mathrm{cfu} / \mathrm{g}$, respectively. In addition, all the samples analyzed are free of Salmonella sp. The microbial loads of the samples of the two sampling sites revealed that there was no significant difference between the various parameters investigated in Bohicon and Hilla-Condji.

\subsection{Discussion}

The microbiological analysis of barbecued mutton sold at Bohicon and Hilla-Condji bus stations revealed high levels for total viable counts, fecal coliforms and $E$. coli, sulphite-reducing anaerobes, $S$. aureus, yeasts and molds. Samples of the two sites were contaminated beyond the tolerable limits required by the French regulations. The high total viable count confirms that barbecued mutton commonly known as "tchachanga", sold at Bohicon and Hilla-Condji bus stations, is processed and sold in poor hygienic conditions. The product is poorly covered or not covered at all making it prone to pollution by the ambient air generated by cars, motorcycles and insects in these bus stations. This exposure environment was mentioned in the diagnostic study carried out by Agli et al. [1]. The vendors of these stations are generally installed at the edge and along the roads, which bring them even closer to aerosols produced by mobile gears. This

Table 2. Variation of the microbial loads in barbecued mutton per sampling sites.

\begin{tabular}{|c|c|c|c|c|c|c|}
\hline \multirow{2}{*}{ Variable } & \multicolumn{2}{|c|}{ Bohicon } & \multicolumn{2}{|c|}{ HillaCondji } & \multirow{2}{*}{ Significance } & \multirow{2}{*}{$\begin{array}{l}\text { Standards } \\
(\mathrm{cfu} / \mathrm{g})\end{array}$} \\
\hline & $\mathbf{M}$ & SE & $\mathbf{M}$ & SE & & \\
\hline TVC $\left(10^{8} \mathrm{cfu} / \mathrm{g}\right)$ & 3.96 & 3.19 & 5.51 & 1.97 & NS & $3 \times 10^{5}$ \\
\hline $\mathrm{FC}\left(10^{3} \mathrm{cfu} / \mathrm{g}\right)$ & 3.81 & 1.41 & 10.3 & 4.28 & NS & 10 \\
\hline E. $\operatorname{coli}\left(10^{3} \mathrm{cfu} / \mathrm{g}\right)$ & 0.952 & 0.352 & 2.57 & 1.07 & NS & - \\
\hline SRA $\left(10^{0} \mathrm{cfu} / \mathrm{g}\right)$ & 194 & 106 & 817 & 729 & NS & 30 \\
\hline$S$. aureus $\left(10^{3} \mathrm{cfu} / \mathrm{g}\right)$ & 3.12 & 1.57 & 3.57 & 2.71 & NS & $10^{2}$ \\
\hline Salmonella (cfu/25g) & absence & absence & Absence & absence & - & Absence \\
\hline $\mathrm{YM}\left(10^{2} \mathrm{cfu} / \mathrm{g}\right)$ & 9.61 & 5.6 & 12.14 & 5.63 & NS & - \\
\hline
\end{tabular}

M: mean; SE: standard error; NS: not significant ( $\mathrm{p}>0.05)$; TVC: Total viable count; FC: fecal coliforms; SRA: Sulphite-reducing anaerobes; YM: Yeats and Molds; Standards: DGAL (2000). 
total flora, which include pathogenic microorganisms and spoilage germs, are higher in this study than those reported $\left(1.43 \times 10^{6}\right.$ and $\left.1.75 \times 10^{7} \mathrm{cfu} / \mathrm{g}\right)$ by Baba Moussa et al. [10] and Ahouansou [13] on the tchachanga sold in Cotonou. The high total viable count in the samples have a double effect. From the technological point of view, this implies that the process of microbial spoilage of the samples is strongly involved and, on the hygienic level, suspects the presence of pathogenic microorganisms in the products.

The average fecal coliforms loads in the samples are one hundred times higher than that prescribed by the standards, which is $10 \mathrm{cfu} / \mathrm{g}$. These high levels of fecal coliforms that are indicators of fecal contamination are evidence of the inadequate processing of this food, which is prepared in low hygienic conditions with high risks of cross-contaminations [14]. Moreover, the contamination of samples by fecal coliforms and particularly $E$. coli also indicates a lack of personal hygiene and mainly testifies a lack of hands washing among handlers. Unwashed hands usually carry fecal microorganisms (E. coli, other heat-resistant bacteria), which are often responsible for diarrheal diseases and gastroenteritis [15] [16].

The average microbial loads in $S$. aureus $\left(3.12 \times 10^{3} \mathrm{cfu} / \mathrm{g}\right.$ and $3.57 \times 10^{3} \mathrm{cfu} / \mathrm{g}$ respectively at Bohicon and Hilla-Condji stations) are higher than those reported (0 cfu/g and $130 \mathrm{cfu} / \mathrm{g}$ ) by Anihouvi [9] and Baba Moussa et al. [10] in the same product in Cotonou. They are; however, lower than that obtained $(1.5 \times$ $10^{5} \mathrm{cfu} / \mathrm{g}$ ) by Ahouansou [13] in Hausa barbecues sold in Cotonou. The presence of $S$. aureus in the samples represents a serious health risk to consumers. $S$. aureus produces enterotoxins (thermostable) whose ingestion causes food poisoning that can lead to sudden death by shock.

The SRA count showed that "tchachanga" samples contained average microbial loads of $194 \mathrm{cfu} / \mathrm{g}$ and $817 \mathrm{cfu} / \mathrm{g}$ respectively at Bohicon and Hilla-Condji bus stations. These values are considerably higher than the $2 \mathrm{cfu} / \mathrm{g}$ reported by Baba Moussa et al. [10]. The presence of SRAs in "tchachanga" could be explained by an insufficient heat treatment or a cross-contamination of the samples by these telluric strains which are carried by the dust. There is therefore a risk of food poisoning to consumers because these microorganisms might be strains of Clostridium perfringens or Clostridium botulinum producing toxins detrimental to human health. Botulinum toxins and tetanus toxins are the most active poisons known, and 100 grams of these toxins is enough to suppress all human life on the surface of the globe. They are 15,000 times more active than the most toxic chemical, aconitine at equal mass [17].

Our study revealed a significant contamination of tchachanga by yeasts and molds $\left(9.61 \times 10^{2} \mathrm{cfu} / \mathrm{g}\right.$ in Bohicon and $12.14 \times 10^{2} \mathrm{cfu} / \mathrm{g}$ in Hilla-Condji). These values are higher than that $(53 \mathrm{cfu} / \mathrm{g}$ ) obtained by Baba Moussa et al. [10]. This non-negligible presence of yeasts and molds in this commodity is ascribed to the insufficient cooking of the meat for the destruction of mold spores. They could also be due to cross-contamination of the product by these spores or also to re- 
cycling products. The presence of yeasts and molds can strongly influence the hygienic quality of this meat because some species of mold synthesize toxic metabolites, mycotoxins under certain conditions, making them potentially injurious for human health [18].

The absence of Salmonella sp in all samples analyzed is a guarantee of food safety against salmonellosis. This result is consistent with that obtained by Baba Moussa et al. [10].

In sum, braised sheep meat investigated microbiologically in both target areas is of unsatisfactory quality and presents health risks to consumers.

\section{Conclusion}

The present study evaluated the microbiological quality of "tchachanga" sold at Bohicon and Hilla-Condji bus stations. Results show that "tchachanga" sold in these two sites is of low microbiological quality and therefore does not guarantee safety of consumers. Moreover, results obtained show that there is no significant difference between the microbial loads obtained in the two sites. It is necessary to raise awareness in all stakeholders in this sector to respect good hygienic practices during preparation, handling and sale, to intensify checks on these products and to propose ways of improving the quality of this ready-to-use food in order to preserve public health. In order that this work may arouse people attention to food safety, it is better to focus on communication near authorities, stakeholders and consumers regarding risks associated with these products.

\section{References}

[1] Agli, K.C., Sodjinou, E. and Singbo, G.A. (2004) Diagnostic socio-economique du secteur de l'Alimentation de rue à Cotonou. Rapport 2004. 100 p.

[2] FAO (1998) Food and Nutrition. Paper No. 46, Street Foods, FAO Report, Yogyakarta, Indonesia, $90 \mathrm{p}$.

[3] Egounléty, M. (1997) Contibution de l'artisanat alimentaire à l'approvisionnement alimentaire des villes en Afrique. Séminaire sous-régional FAO-ISRA sur l'approvisionnement et la distribution alimentaires des villes en Afrique. Dakar, Sénégal, $46 \mathrm{p}$.

[4] Gagara (2010) Evaluation de la qualité hygiénique des boissons vendues aux abords des rues de Cotonou et d'Abomey-Calavi. Mémoire de master en Norme, contrôle de qualité et technologie alimentaire. Universitéd'Abomey-Calavi, 97 p.

[5] Newell, G.D., Koopmans, M., Verhoef, L., Duizer, E., Aidara-Kane, A., Sprong, H., Opsteegh, M., Langelaar, M., Threfall, J., Scheutz, F., van der Giessen, J. and Kruse, H. (2010) Food-Borne Diseases-The Challenges of 20 Years Ago Still Persist While New Ones Continue to Emerge. International Journal of Food Microbiology, 139, S3-S15. https://doi.org/10.1016/j.ijfoodmicro.2010.01.021

[6] Joeffin, C. (2003) Microbiologie Alimentaire. 5ème édition, Canopé-CRDP de Bordeaux, France, 212 p.

[7] Chauliac, M., Bricas, N., Ategbo, E., Amoussa, H.W. and Zohoun, I. (1998) L'alimentation hors du domicile des écoliers de Cotonou (Bénin). Cahiers Santé, 8, 101-108. 
[8] Yehouenou, B., Wotto, V., Bankolé, H., Sessou, P., Noudogbessi, J.P. and Sohounhloue, D. (2010) Chemical Study and Antimicrobial Activities of Volatile Extracts from Fresh Leaves of Crassocephalum rubens (Juss \& Jack) S. Moore against Food-Borne Pathogens. Scientific Study \& Research, Chemistry \& Chemical Engineering, Biotechnology, Food Industry, 11, 343-351.

[9] Anihouvi, D.G. (2007) Evaluation de la qualité microbiologique du tchachanga, une viande de mouton braisée vendue dans les rues de Cotonou. Thèse d'Ingénieur Agronome-FSA/DNSA, 81.

[10] Baba-Moussa, L., Bokossa, Y.I., Baba-Moussa, F., Ahissou, H., Adeoti, Z., Yehouenou, B., Mamadou, A., Toukourou, F. and Sanni, A. (2006) Etude des possibilités de contamination des aliments de rues au Bénin : cas de la ville de Cotonou. Journal de la Recherche Scientifique de l'Universite de Lome, 8, 149-156.

[11] SAS (Statistical Analysis System) (2006) User' Guide. 13th International Symposium, Seoul.

[12] DGAL (Direction Générale de l'Alimentation) (2000) Guide législatif règlementaire français N 8155 du 12 Décembre relatif aux critères microbiologiques applicables aux denrées alimentaires. $32 \mathrm{p}$.

[13] Ahouansou, A.E. (1993) Les aliments de rue à Cotonou (Bénin): Caractérisation socioéconomique des vendeurs et des consommateurs et qualité hygiénique des aliments. Thèse d'Ingénieur Agronome-FSA/UNB, 98 p.

[14] Cuq, P. (2013) Cours de microbiologie alimentaire. Université de Montpellier, 95 p.

[15] FAO/OMS (1990) Draft Code of Hygienic Practice for the Preparation and Sale of Street.

[16] Owhe-Ureghe, O.E., Ekundayo, A.O., Agboniahor, D.E., Oboh, P.A. and Orhue, P. (1993) Bacterial Examination of Somme Ready-to-Eat Foods Marketed in Ekpoma, Edo State of Nigeria. Nigerian Food Journal, 11, 45-52.

[17] Leyral, G. and Vieling, E. (1997) Microbiologie et toxicologie des aliments; Hygiène et sécurité alimentaire. Secondeédition, $271 \mathrm{p}$.

[18] Sessou, P., Farougou, S., Ahounou, S., Yedomonhan, H., Azokpota, P., Youssao, I. and Sohounhloue, D. (2013) Comparative Study of Antifungal Activities of Six Selected Essential Oils against Fungal Isolates from Cheese Wagashi in Benin. Pakistan Journal of Biological Sciences, 16, 1751-1757. https://doi.org/10.3923/pjbs.2013.1751.1757 
Submit or recommend next manuscript to SCIRP and we will provide best service for you:

Accepting pre-submission inquiries through Email, Facebook, LinkedIn, Twitter, etc. A wide selection of journals (inclusive of 9 subjects, more than 200 journals)

Providing 24-hour high-quality service

User-friendly online submission system

Fair and swift peer-review system

Efficient typesetting and proofreading procedure

Display of the result of downloads and visits, as well as the number of cited articles Maximum dissemination of your research work

Submit your manuscript at: http://papersubmission.scirp.org/

Or contact aim@scirp.org 